\title{
Triple Talaq Bill in India: Muslim Women as Political Subjects or Victims?
}

\section{Esita Sur ${ }^{\dagger}$}

\section{Abstract}

The recent proposed Muslim Women (Protection of Rights on Marriage) Bill 2017 has raised the new issues, which were long due to Muslim women in India. It has not only criminalised the practice of instant tin talaq (divorce), but also signifies the government's intervention in defining the notion of gender justice to Muslim women. Importantly, this development not only highlights an emerging Muslim women's activism in India but also an articulation of gender justice from within the community. However, an array of criticisms is also sprouting up against the Bill from different corners of the community, including Muslim women's groups. The article is an attempt to address the multiple facets of the Bill; it also argues that the talaq issue alone cannot constitute the core of gender justice rather the interplay of various factors like Hindutva, communal violence and the marginal location of the Muslim community needs to taken into account to understand Muslim women's question in India.

Keywords: Gender Justice, Talaq-e-Biddat, Hindutva, Marginality and Muslim Women, India

\section{Introduction}

Since the 22nd August 2017, Muslim women have acquired a centre-stage in various debates and discussions, especially in the media. The Supreme Court's judgment that the practice of instant triple talaq is unconstitutional created much hustle-bustle in the public sphere. The Shah Bano Case in 1985 and the subsequent legislation titled Muslim Women (Protection of Rights on Divorce) Act 1986 brought about the issues of divorce and maintenance into the limelight. In 2016, Shayara Bano had filed a petition in the apex court against the malpractice of triple talaq and became the part of that historical judgment. From 1985 to 2016, many Muslim women approached the court for justice. Moreover, the emergence of Muslim women's groups like the Bharatiya Muslim Mahila Andolan (BMMA), the Awaaz-e-Niswaan (AeN) and the All India Muslim Women Personal Law Board (AIMWPLB) have raised voices on these gendered-cultural discriminations; ripples of these women's activism against the malpractice of talaq and polygamy are also creating waves of resistance in different corners of society. I hope that their images as victims may be, to some extent, altered as petitioners or fighters. In the light of these backdrops, this article is an attempt to review the proposed Muslim Women (Protection of Rights on Marriage) Bill 2017 that has failed to be passed in the Parliament of India. The first part of the article aims to contextualise Muslim women and the proposed bill. Following this, the article discusses the paradoxes of the bill and the political contexts entailed. Finally, it tries to answer as to whether the bill will mediate Muslim women's empowerment.

\section{The Bill and Muslim Women in India: The Context}

Before different dimensions of the Muslim Women (Protection of Rights on Marriage) Bill are addressed, it is essential to locate Muslim women in the broader Indian context. Dominant perceptions of Muslim women in India have revolved around the tropes of talaq, polygamy, Muslim personal law and purdah (veiling) and it represents a homogenised image of these women's victimhood. The issues like talaq and polygamy have gained more prominence over the socio-economic marginalisation in terms of projecting their identities as passive victims. As

\footnotetext{
${ }^{\dagger}$ Assistant Professor in Political Science, Scottish Church College, Kolkata, Email: esitasur@rediffmail.com (C) 2018 Sur. This is an Open Access article distributed under the terms of the Creative Commons Attribution License (http://creativecommons.org/licenses/by/2.0), which permits unrestricted use, distribution, and reproduction in any medium, provided the original work is properly cited.
} 
the feminist lawyer and activist, Flavia Agnes mentions that the stories of discriminations and exploitation of Gudiya $(1999)^{1}$ and Imrana $(2005)^{2}$ get more weightage over those Muslim women's agency- who has struggled for justice in the courtroom. Surprisingly, the term 'backwardness' is always equated with these cultural practices but not with educational and economic marginalisation. Muslim women's varied experiences based on class, region and sects can challenge this image; it also creates a space for locating Muslim women's activism. Moreover, the community's response to the issue of talaq and Muslim personal law reform has also been diverse. The Triple Talaq Bill also known as The Muslim Women's (Protection of Rights on Marriage) Bill highlights both: Muslim women as victims and as agents of change. While the journey from Shah Bano (1985) to Shayara Bano case (2016) continues to depict their problems and vulnerabilities, it also throws light on their agency and resistance to patriarchal oppression. It has also exhibited how these women's struggle for justice has created an array of reactions within the community and more space for politics and manipulation.

\footnotetext{
${ }^{1}$ Gudiya's case came into media focus when Mohammad Arif (her husband) had gone missing during the 1999 Kargil war. During the five-year absence of Arif, who was presumed to be dead after initially being declared a deserter, Gudiya had remarried Taufiq and carried his child. On his return to his native village, Arif found his wife Gudiya was married to Taufiq. However, the village council reunited Arif and Gudiya. Taufiq tried to get Gudiya back but the council ruled in favour of Arif, and Gudiya was made to live with Arif. Sadly, Gudiya passed away in December 2006 (Kumar 2006, 1).

2 In 2005, a 70- year-old father-in-law in a remote village of Uttar Pradesh raped his daughter-in-law named Imrana. The religious leaders and the caste panchayat issued the fatwa (religious decree) via which Imrana had to marry her father-in-law and consider her husband as her stepson. The Women's Commission and the state could not do anything on the ground that it was an internal affair of the community (Agnes 2012, 127).

${ }^{3}$ The Muslim Women (Protection of Rights on Marriage) Bill, 2017, PRS Legislative Research, available at: http://www.prsindia.org/billtrack/the-muslim-womenprotection-of-rights-on-marriage-bill-2017-5008/ (last accessed on 27.02.2018).

4 The Muslim Women (Protection of Rights on Marriage)Bill, 2017, Bill No. 247 of 2017, available at: PRS
}

The article intends to examine different dimensions of the Bill. It also argues that the Bill should not be straight-jacketed under the guise of gender justice for Muslim women; rather the political field and socio-economic contexts, in which the community and women survive, must be taken into consideration. Therefore, the relationship between the Bill, women and overall condition of the community needs to be analysed in the Indian context. The proposed Bill for Muslim women must be located in the broader arena of culture, economy and politics; the question of gender justice cannot be imposed from the top; rather it has to be based on the marginal perspective.

\section{The Contradictory Dimensions of the Bill}

In this context, the Law and Justice Minister Mr Ravi Shankar Prasad introduced the Muslim Women (Protection of Rights on Marriage) Bill in December $2017^{3} 4$ in the Lok Sabha. This Bill has been shelved after the Rajya Sabha has sent it to the Select Committee for detailed scrutiny. It has also given rise to a bunch of criticisms, especially the clause on 'criminalisation of talaq'. The Bill declares the pronouncement of talaq-e-biddat ${ }^{5}$ as illegal and void. According to

Legislative Research, available at: http://www.prsindia.org/uploads/media/Muslim\%20Wo men\%20(Protection\%20of\%20Rights\%20on\%20Marriage )/Muslim\%20Women\%20(Protection\%20of\%20Rights\%2 0on\%20Marriage)\%20Bill,\%202017.pdf (accessed on 27.02.2018).

${ }^{5}$ Talaq is a procedure that can be initiated by the husband alone without the consent of his wife. Besides, the exercise of talaq is extra-judicial, and in no way subject to external check. Technically, the power of the husband to divorce is absolute. Talaq may be pronounced in a number of ways, e.g., (1) Ahsan-e-talaq (2) Hasan-e-talaq (3) Biddat-e-talaq. The Ahsan form of talaq does not take place in a single sitting nor can it take place during menstruation. Iddah is observed during the period following menstruation (that is tuhr or the purity) where two arbitrators from both sides are appointed to bring about reconciliation. During the iddah period, the marriage is not dissolved. If reconciliation takes place, the marriage is saved, and no nikah is needed. In Ahsan talaq, even after the third pronouncement of talaq, after the 'iddah' period, the marriage is revocable (Sur 2014, 4352). The man can remarry his divorced wife. This practice is in accordance with the teaching of the Quran and according to the Sunna rules. Both the Sunni and Shia schools approve of talaq-e-ahsan. On the contrary, Talaq- 
clause 3 of the Bill, any pronouncement of talaq by a person upon his wife by words - either spoken or written or in any electronic form or in any other manner- shall be void and illegal. A man who pronounces talaq on his wife will be punished with a jail term and fine. This Bill also makes the pronouncement of talaq-e-biddat a non-bailable offence. Clause 4 of the Bill states, "Whoever pronounces talaq referred to in section 3 shall be punished with imprisonment for a term which may extend up to three years and fine". Moreover, clauses 5 and 6 of the Bill highlights, "a married Muslim woman upon whom talaq is pronounced, shall be entitled to receive from her husband such amount of subsistence allowance for her and dependent children," and "shall be entitled to custody of her minor children in the event of pronouncement of talaq by her husband" (Radhakrishnan, 2017). The Law and Justice Minister Ravi Shankar Prasad, in the statement of objects and reasons attached to the Bill, conveyed that this legislation would help in ensuring the larger Constitutional goals of gender justice and equality of married Muslim women and in securing their fundamental rights of non-discrimination and empowerment.

Many had argued that there was no requirement of the Bill as the judgment was enough to protect the rights of these women. The ground realities exhibited that the instances of triple talaq continued even after the judgment. The legislation is required to maintain the gravity of the judgment. However, it contains not only contradictory but also arbitrary clauses that demand more debates and discussions to do a full proof act. The Bill, as passed by the Lok Sabha, is based on the following provisions: a) the 'utterance' of tin talaq in one setting non-bailable and a cognisable act; therefore, it leaves no room for reconciliation. A probable argument is: why should these women look for reconciliation with

e-Biddat is a form of divorce, which is criticised, as it goes against the rules laid down by the Quran. However, the Sunna approves it. In this form of talaq, the husband unilaterally, without the consent or knowledge of the wife, pronounces talaq. The husband can pronounce talaq once or three times simultaneously, without paying their husbands practising arbitrary talaq against them? Their socio-economic vulnerabilities and compulsions shape their choices for reconciliations. It also penalises a Muslim husband for a legally void act. The judgment had already declared that talaq-e-biddat is invalid and unconstitutional; therefore, it does not dissolve the marriage. How can the Bill penalise a Muslim husband for up to 3 years just for 'utterance', which does not dissolve the marriage? During his imprisonment, how will the maintenance question be solved for a Muslim woman and their dependent children? The Bill proposes that Muslim woman can approach the District Magistrate regarding this issue. It ignores the fact there is a direct relationship between imprisonment, livelihood earning and maintenance. Moreover, the Bill makes utterance of tin-talaq as a non-bailable and non-cognisable act, which adds further complications for Muslim women. The dimension of 'criminality' in inter-personal relations may also be considered as detrimental to these women, as this leaves room for further manipulation. Are these women capable enough to handle these repercussions, especially the issue of the social boycott from the community? These provisions may further increase Muslim women's dependence on Sharia Courts or Jamaat as the civil court procedures are getting more complicated with the 'criminality' aspect. Anindita Chakrabarty and Suchandra Ghosh's study (2017) on Muslim Family Courts revealed the procedural dimension of Muslim personal law and raised a pertinent question: how are Muslim family and civil cases adjudicated in India? They have successfully pointed out that popular discourses highlight certain dimensions of Muslim personal law, but it hardly reflects how Muslim women take help from the multiple legal actors like Sharia courts, women's groups, clergy and religious organisations. Even the Supreme Court

attention to the fact whether the wife is in a state of tuhr. The Prophet did not approve of this form of divorce (Sur $2015,4-16)$. According to this form of talaq, a man would pronounce talaq three times in one sitting, and this would be understood as if talaq had been given thrice. 
judgment in 2014 gave recognition to these religious adjudication units, known as "alternative dispute resolution" (ADR) forums in the legal landscape of family law in India and made it clear that the sharia court was an effective arbitrator, mediator, negotiator and conciliator in matters of family and civil disputes and were not in conflict with the secular judiciary (Chakrabarty and Ghosh, 2017). Therefore, is criminalising 'utterance' of legally nullified words a full-proof mechanism to secure gender justice? This stringent Bill may further aggravate a clear distinction between the procedural complications of civil law and community mechanisms for justice.

The contradictory dimensions of this Bill will receive further clarity if it is compared to those Muslim-majority countries, which have already outlawed the practice of triple talaq. The Islamic countries like Bangladesh, Pakistan, Turkey, Malaysia, Indonesia and Egypt have reformed their divorce laws. The provision of criminalisation is valid in Bangladesh and Pakistan (Kohli and Narayanan, 2017). In these countries, precondition of divorce is based on the following points: a) failure of reconciliation between the husband and the wife is must for talaq; b) involvement of either the civil or arbitration court or the religious authority is an integral part of the process; c) moreover, the process of divorce is not complete without an overall enquiry on the causes of rift or reasons behind the failure of reconciliation by these authorities. In Turkey, the entire procedure takes place in the civil court only. The problem in India is that the provision of tin talaq has been misused via verbal and non-verbal forms like SMS, WhatsApp and email. Most importantly, this kind of pronouncement and occurrence always takes place without the consent of their wives and family members. Unfortunately, the religious authorities like Qazi and Maulana, sometimes, misinterpret their knowledge to suppress women's rights. Comparative analysis enables us to understand that the Bill would have given more emphasis on the mechanism of delivering justice rather than criminalising the process.

In Shamim Ara case (2002), the Supreme Court had already laid down the process of divorce. The court was of the firm opinion that if talaq was to be effective, it had to be pronounced. The term 'pronounce' incorporates: 'to proclaim, to utter formally, to declare and to articulate'. The verdict also emphasised that the interpretation of talaq must be by Quranic injunctions and a mere plea in the written statement submitted to the court that talaq was given cannot be treated as a pronouncement of talaq by the husband on the wife (Agnes 2012, $65)$. Therefore, more importance would have been given to developing a proper institutional framework of delivering justice based on the Supreme Court judgment, 2017. Creation of a shortcut to gender justice is not much appealing to us. Importantly, it projects a lopsided view on gender justice, which remains political and does not consider the socio-economic wellbeing of these women. This Bill is a clear attempt to create a homogenised group of 'oppressor Muslim husbands' and 'helpless Muslim women victims'. However, it is not as simple as it seems to be. The practice of instant tin talaq has a class dimension and cannot be posited as the problem of entire community. The lack of education and economic development always paves the way for multi-layered marginalisation, especially for women. The Bharatiya Muslim Mahila Andolan's (BMMA) ${ }^{6}$ - one of the petitioners in the Supreme Court against triple talaq - conducted a survey on Muslim women's views on personal law reforms in Maharashtra. $90 \%$ of its sample size asked for a ban on the misuse of instant tin talaq, and this report acts as the weapon in their struggle for rights. Their report titled Seeking Justice Within Family: A National Study on Muslim Women's Views on Reforms in Muslim Personal Law has also shown that those women who raised voices against talaq were socio-economically equally

organisation also raises voice for socio-economic development of the community (BMMA Report, 2012).

\footnotetext{
${ }^{6}$ The BMMA is one of the Muslim women's organisations, which emerged in 2007 in Mumbai. It mainly works against the practices of talaq and polygamy. This
} 
vulnerable. Another important point is that it also highlights the rise of collective struggle of women from within and the emergence of a gender-inclusive interpretation of Islam from the marginalised. In 1985 during Shah Bano case, the voice for change did not come from Muslim women as the collective. In 2017, their views have taken a more organised shape in different parts of India. The present government can locate them as resisters and negotiators; this transformation needs to be addressed.

\section{Bill and the Political Context}

An overall evaluation of the Bill cannot deny the politics behind it. The primary purpose as declared by the government is gender justice for Muslim women. The BJP (Bharatiya Janata Party) government is determined to save them from the unjust practice of tin talaq. During the Uttar Pradesh Elections in 2017, Narendra Modi promised gender justice to them. Apparently, it seems to be very simple and loaded with the spirit of welfare; however, the reality denies the simplicity. A proper assessment of the Bill is not possible unless the socio-economic and political contexts are not taken into consideration. The government, which is championing the Bill for Muslim women, has closely been associated with projecting Muslims as 'others' in Indian culture, history and politics. It is also aiming nothing but creating another stereotype as well as a separate class of 'criminal' Muslim husbands. Abdul Shaban's study shows that most of all Muslim ghettos in Mumbai are considered to be the den of criminals by the administration; and these perceptions are also related to the stigmatisation of the community (Shaban 2012, 215).

\footnotetext{
7 The Srikrishna Commission Report was published in 1998. This report mainly aimed at unearthing the reasons behind the breaking out of communal violence between the Hindus and the Muslims in Mumbai after the demolition of Babri Masjid in 1992-93. It clearly stated the involvement of the political parties like the Vishwa Hindu Parishad (VHP) and the Rashtriya Swayam Sevak (RSS) in the riots. It provided a detailed account of the role of hate speeches used by the right-wing political leaders in inciting violence against the Muslim community and this report also highlighted the involvement of state machinery in violence. Moreover, it also explained how
}

A further investigation into the relationship between the Rightist parties and Muslims also exhibits several instances of their biased involvement in communal violence. The Srikrishna Commission Report (1998) clearly explained the role of the ruling party and administration in Mumbai communal riots in 1992-93. ${ }^{7}$ The memory of Gujarat carnage in $2002^{8}$ is still alive. As Dibyesh Anand mentioned, the anti-Muslim violence in Gujarat in 2002 indicated how the forces of Hindutva acted as tools to legitimise violence; killers became defenders and death as non-death (Anand 2012, 297). The question is: what has the role of the government been in delivering justice to those Muslim women victims? It seems that gender justice on tin talaq is easier than delivering justice to riot victims who are also supposed to be Muslim women. In this context, the new avatar of the government as the messiah of these women is not beyond scrutiny. The question, which ponders over our minds: are Muslim women are being used as pawns? Is it an aggravation of homogenised stereotypes of Muslims as 'criminals' and women as 'victims'? The government did not even bother to consult these women's groups and the All India Muslim Personal Law Board on the Bill. Muslim women's groups, which fought against talaq, did not demand criminalisation. Therefore, can the question of reform and change be addressed without considering the views from within? It is to be remembered that women are not isolated from their community. This Bill, to a large extent, has hijacked the contribution made by these groups. However, the All India Muslim Personal Law Board's standpoint on personal law reform has always been very problematic.

the religious symbols and practice like Maha aarti and Namaz become the political sites of contestation and mobilisation for revenge (Punwani 2012, 186-88).

8 The Gujarat carnage is related to Godhra train-burning communal violence, which had begun with a fire in coach S6 of the Sabarmati Express on 27.02. 2002. It had led to massive sectarian violence between the Hindus and the Muslim in different parts of Gujarat. After 15 years of violence, still, it is unknown that who had lit the fire. However, various reports have highlighted the role of the Modi government in this violence (Guruswamy, 2017). 
Since 2005, Muslim women's groups had continuously asked for banning the practice of tin talaq, but they have not paid attention to them. It also highlights the old debate on gender, community and the state in which not only the cultural discriminations but also the lack of state intervention in private tend to be justified on the ground of the minority religion, culture and identity. The government's intervention highlights the failure of the AIMPLB as the spokesperson for the women.

A comparative assessment of Muslim Women's Act (1986) and proposed Triple Talaq Bill (2017) enables us to understand the politics behind this venture. The former addressed women's rights in divorce and the later focused on marriage. It highlights the influence of majority-minority dynamics behind the Bill; moreover, the power play behind the government intervention cannot be ruled out. In Shah Bano Case, the Supreme Court delivered its verdict in favour of Muslim women's right to maintenance. However, the Rajiv Gandhi government could not implement the verdict due to vociferous opposition by the conservative religious leadership; it also moved the right of a divorced Muslim woman from the purview of the general law of maintenance under S125 of the Cr.PC ${ }^{9}$ and placed under special legislation. Therefore, Muslim Women's (Protection of Rights on Divorce) Act (1986) replaced the previous recurrent maintenance right by a provision for 'fair and reasonable lifelong maintenance'. If the husband fails to make the settlement, a divorced Muslim woman has the right to approach the Magistrate's court for enforcement of the right under Section 3 of the Act. During this time, many High Courts

\footnotetext{
${ }^{9}$ Section 125 of the Criminal Procedure 1973 is legislation for social justice; it provides an adequate remedy for seeking support. A follower of any religion can apply for maintenance under this section (Agnes, 2012).

${ }^{10}$ Vinayak Damodar Savarkar developed the ideology of Hindutva. He coined this term in 1923 to express the totality of the cultural, historical, and above all the national aspects along with the religious one, which defines the Hindu people as a unitary category. It comprehends the Hindu people as the Hindu Rashtra; Hindutva is the ideology of Hindu Rashtra. The doctrine is also based on the concepts of Pitribhumi (Fatherland) and
}

interpreted this judgment positively, and women could secure their maintenance rights. However, the opposition criticised the Congress government for its appeasement policies towards the minority community; raised questions on the nature of Indian secularism where the relationship between religion, personal laws and fundamental rights remains problematic.

Moreover, the Bharatiya Janata Party's (BJP) politics and outlook towards the community has been problematic on several accounts, and the recent Bill is just one of its reflections. The Triple Talaq Bill (2017) tends to serve justice and security for Muslim women. However, the rise of right-wing Hindutva ${ }^{10}$ politics since the 1990s itself represented the Muslims as 'danger' and 'threat to security'. As Dibyesh Anand rightly points out that Muslims are discursively produced as enemies and sources of insecurity. Therefore, 'crimnalisation' clause in the proposed Bill further reinforces their images as 'other'. Since a mere utterance of the word "talaq" does not dissolve the marriage and no injury is caused to the state or an individual, how can it be construed as a criminal offence? After the constitution bench's ruling, the word "talaq" has lost its legal validity and power to dissolve a Muslim marriage (Anand 2012, 287-290).

The Muslim Women (Protection of Rights on Marriage) Bill, 2017 is meant as a throwback to the statute enacted in 1986, the Muslim Women (Protection of Rights on Divorce) Act. Through a creative interpretation, this statute has protected a divorced Muslim wife's lump sum maintenance as fair and reasonable settlement, a right that has far more advantages for a

Punyabhumi (Holyland) to which Muslims and Christians do not belong to; moreover, in Savarkar's words Mohammadan and Christian communities possess all the essential qualifications of Hindutva but the main point of difference is that: they do not look upon India as their Holyland. Their Holyland is far off in Arabia and Palestine. Their mythology and Godmen, ideas and heroes are not the children of the soil. Consequently, their names and outlook smack of foreign origin. Their love is divided. Hence, it leads to the development of the self-contained political ideology of hate (Noorani 2015, 64-68). 
divorced wife than the earlier provision and has better protected the rights of divorced Muslim women than their counterparts from other religions. Despite this, popular discourses tried to portray the Muslim Women (Protection of Rights on Divorce) Act as a statute that has deprived Muslim women of their crucial right of maintenance. The enactment is viewed as a backward move of "Muslim appeasement" by the Rajiv Gandhi-led Congress government and a glaring example of the failure of the state's commitment to secularism at the behest of Muslim religious fundamentalists. This new Bill is trying to provide a more 'radical view' on marriage and divorce and building the image of Hindu man as the saviour of Muslim sisters (Mandal, 2017). In the words of Flavia Agnes, the Muslim male is projected as backward, obscurantist, and misogynist, and the women as helpless victims and devoid of agency (Agnes, 2018). Therefore, the notion of gender justice has taken a more political shape in our popular discourses.

\section{Conclusion: Is this Bill Going to be the Symbol of Muslim Women's Empowerment?}

The article set out to critically review The Triple Talaq Bill introduced on 28 December 2017 in the Lok Sabha by Mr. Ravi Shankar Prasad, the honourable Minister of Law and Justice. Now the most important question is: will the bill really serve the purpose of Muslim women in India? Should the abolition of the practice of talaq be considered as the only mechanism for their empowerment? The most important question: is this Bill an illusion or symbol of gender justice for Muslim Women? The need for protection in marriage is always an important factor; however, the overall socio-economic condition of the community and its mind-set is equally a significant dimension to be addressed. What needs to be recognised is: discriminations both in public and private spheres have to be addressed; a partial perspective on gender justice, bypassing their socio-economic vulnerabilities, will not empower these women. The 'protectionist' approach of all Bills and Acts will remain fruitless unless there are proper education and overall development for the women. The responsibility of family and community in this respect should also be counted, as the cultivation of values is bestowed upon them. It cannot be denied that whenever Muslim women have raised voices against injustice, they have received sheer criticisms from within the community. Ishrat Jehan, who was one of the petitioners against the practice of triple talaq and polygamy in the Supreme Court from Kolkata, faced tremendous opposition from her family members and the community. She was considered as 'anti-men' and 'un-Islamic' woman. Therefore, the mindsets for reform and change have to be developed from within the community. Better to say, this opposition is also an important part of progress. Most importantly, the government, which is propagating gender justice for Muslim women, must create the atmosphere conducive to peace and justice. The silence of the Modi government on several issues like mass lynching and increasing power of cow invigilation committees and the Hindutva forces highlight its attitude towards the community. What needs to be recognised is that no reform can be trapped in a binary between constitutional laws versus personal law, freedom versus religion, Article 14 (right to equality) versus Article 25 (right to religion). This watertight division emerges from a less-nuanced understanding of Muslim women's lives and the perception that they are mere 'objects of reforms' bereft of agency. Therefore, the notion of gender justice cannot only be defined politically and from a maleworldview; rather an inclusive approach is required, which addresses the voices from the below.

\section{References}

Agnes, Flavia (ed). (2012). Defending Muslim women's rights: Bridging Muslim personal law and court judgements, Mumbai: Majlis.

Agnes, Flavia (2018). The bill criminalising instant triple talaq is against gender justice, available at: www.majlislaw.com (last accessed on 10.01.2018).

Anand, Dibyesh (2012). The violence of security: Hindutva's lethal imaginaries. In Minority Studies, (ed) Rowena Robinson, 
New Delhi: Oxford University Press, pp. 287-304.

BMMA Report. 2011-12. BMMA: Mumbai.

Chakrabarti, Anindita and Suchandra Ghosh (2017, 9th December). Judicial reform vs adjudication of personal law: View from a Muslim ghetto in Kanpur, Economic and Political Weekly, Volume 52 (49), available at: www.epw.in (last accessed on 10.01.2018).

Guruswamy, Mohan (2017, 27th February). 15 years after Godhra, we still don't know who lit the fire. The HindustanTimes, available at: www.hindustantimes.com (last accessed on 26.02.2018).

Kohli, Kaveesha and Divya Narayanan (2017, 28 December). As India debates triple talaq, here are 9 Islamic countries that have regulated divorce, The Print, available at: www.printin.com (last accessed on 05.01.2018).

Kumar, Arun. (2006, 3rd January). Gudiya Dies. The Hindu, available at: www.thehindu.com (last accessed on 08 .10. 2014).

Mandal, Saptarshi (2017, 22nd December). Instant triple talaq bill: Tabling legislation in Parliament is political move, BJP's attempt to play protector of Muslims, Firepost, available at: www.firepost.com (last accessed on 12.01.2018).

Niaz, Noorjehan Safia and Zakia Soman (2015). Seeking justice within family: A national study on Muslim women's views on reforms in Muslim personal law. Mumbai: Bharatiya Muslim Mahila Andolan.

Noorani, A.G (2015). Savarkar and Hindutva: The Godse connection. New Delhi: Left Word.
Punwani, Jyoti (2012). Police conduct during communal riots: Evidence from 1992-93 Mumbai riots and its implications. In Lives of Muslims in India: Politics, Exclusion and Violence, (eds.), Abdul Shaban, New Delhi: Routledge, pp.208-225.

Radhakrishnan, Sruthi (2017, 28th December). What is the instant triple talaq Bill? The Hindu, available at: www.thehindu.com (last accessed on 6.01.2018).

Shaban, Abdul (2012). Ethnics politics, Muslims and space in contemporary Mumbai. In Lives of Muslims in India: Politics, Exclusion and Violence, (eds.), Abdul Shaban, New Delhi: Routledge, pp.208-225.

Sur, Esita. (2015). Politics of locating Muslim women in Islamic discursive tradition in India. Space And Culture, India, 3(1), 4-16. doi:10.20896/saci.v3i1.135

Sur, Esita. (2014). Revisiting the marginal locations of Muslim women on various sites in India. Space And Culture, India, 1(3), 43-52. doi:10.20896/saci.v1i3.44

The Muslim Women (Protection of Rights on Marriage) Bill, 2017, PRS Legislative Research, available at: http://www.prsindia.org/billtrack/themuslim-women-protection-of-rights-onmarriage-bill-2017-5008/ (last accessed on 27.02-2018)

The Muslim Women (Protection of Rights on Marriage)Bill, 2017, Bill No. 247 of 2017, available at: PRS Legislative Research, available at: http://www.prsindia.org/uploads/media/ Muslim\%20Women\%20(Protection\%20of\% 20Rights\%20on\%20Marriage)/Muslim\%20 Women\%20(Protection\%20of\%20Rights\%2 Oon\%20Marriage)\%20Bill,\%202017.pdf (accessed on 27.02.2018). 